\title{
Multiple Cavitary Nodules Accompanied by Pulmonary Nocardiosis in a Patient with Systemic Lupus Erythematosus
}

\author{
Sistemik Lupus Eritematozuslu Bir Hastada Multipl Kaviter Nodüllerin Eşlik Ettiği \\ Pulmoner Nokardiyoz Olgusu
}

\author{
Zehra Çağla KARAKOÇ, ${ }^{1}$ Şule NAMLI, ${ }^{2}$ Süleyman Tevfik ECDER, ${ }^{3}$ Recep TEKİN ${ }^{4}$ \\ ${ }^{1}$ Department of Infectious Disease and Clinical Microbiology, Metropolitan Hospital, İstanbul, Turkey; \\ ${ }^{2}$ Department of Gastroenterology, Medical Faculty of Dokuz Eylül University, İzmir, Turkey; \\ ${ }^{3}$ Department of Nephrology, İstanbul University İstanbul Medical Faculty, İstanbul, Turkey; \\ ${ }^{4}$ Department of Infectious Disease and Clinical Microbiology, Diyarbakır Children's Hospital, Diyarbakır, Turkey
}

Pulmonary nocardiosis is a chronic suppurative infection that may occur in immunosuppressed patients. It can be self-limited, or it can have an acute, subacute, or chronic course. Radiological diagnosis of pulmonary nocardiosis is difficult because of the very low prevalence of the disease even in immunocompromised patients and is also problematic because the radiographic findings are diverse with no characteristic findings. Multiple nodules and cavitations are more commonly described in acquired immune deficiency syndrome (AIDS) patients but are uncommon in non-AIDS patients. Also, the association of nocardia infection with systemic lupus erythematosus has been described occasionally. In this article, we report a rare case of pulmonary nocardiosis with multiple cavitary lesions and acute respiratory failure in a HIV-negative patient with systemic lupus erythematosus who was receiving corticosteroid treatment.

Key words: Immunosupression; pulmonary nocardiosis; systemic lupus erythematosus.

Pulmonary nocardiosis is an infrequent and severe infection that is most commonly seen in immunocompromised hosts. ${ }^{[1]}$ Immunosuppression is a well-established risk factor for nocardiosis. It is primarily an opportunistic infection. Nocardiosis occurs, in particular, in patients with underlying malignancies,
Pulmoner nokardiyoz, immünosüpresyonlu hastalarda gelişebilen kronik süpüratif bir infeksiyondur. Hastalık kendini sınrlayabilir veya akut, subakut, kronik formda seyredebilir. Pulmoner nokardiyozun radyolojik tanısı, prevelansının immünosüpresif hastalarda bile düşük olması ve ayrıca radyolojik bulguların çok çeşitli olup hastalığa özgü bulgular içermemesi nedeniyle zordur. Birden fazla nodül ve kavitasyon varlığı edinilmiş bağışıklık eksikliği sendromlu (AiDS) hastalarda daha sık olarak tanımlanmakla birlikte AiDS'li olmayan hastalarda nadirdir. Ayrıca eşzamanlı nokardiya infeksiyonu ve sistemik lupus eritematozus varlığı nadiren tarif edilmiştir. Bu yazıda, HIV-negatif olan ve kortikosteroid tedavisi alan sistemik lupus eritematozuslu bir hastada multipl kaviter lezyonlarla ve akut solunum yetmezliğiyle seyreden nadir bir pulmoner nokardiyoz olgusu sunuldu.

Anahtar sözcükler: İmmünsüpresif; pulmoner nokardiyoz; sistemik lupus eritematozus.

chronic lung disease, or disorders of cell-mediated immunity, including human immunodeficiency virus (HIV) infection. It also occurs in those who receive long-term corticosteroid therapy and those who undergo organ transplantation. Radiological diagnosis of nocardiosis is unusual, partly because of the very low

Received: May 5, 2010 Accepted: November 12, 2010

Correspondence: Recep Tekin, M.D. Diyarbakır Çocuk Hastalıkları Hastanesi Enfeksiyon Hastalıkları ve Klinik Mikrobiyoloji Kliniği 21100 Diyarbakır, Turkey. Tel: +90 412 - 2245751 e-mail: rectek21@hotmail.com 
prevalence of the disease, even in immunosuppressed patients, and because it produces an impressive variety of roentgenographic findings. It can also manifest in unexpected ways, especially in immunocompromised patients. Multiple cavitary nodules in pulmonary nocardiosis are uncommonly seen in HIV-negative immunocompromised patients, ${ }^{[1]}$ and they are also very rare in systemic lupus erythematosus (SLE). In this case, we report a rare case of pulmonary nocardiosis with multiple cavitary lesions and acute respiratory failure in a HIV-negative patient with SLE who was receiving long-term corticosteroid treatment.

\section{CASE REPORT}

A 50-year-old male patient was admitted to our hospital with symptoms of fatigue, proximal muscle weakness, and bruising. Two years previously, he had manifested symptoms of arthralgia, arthritis, and edema. Because of these complaints, laboratory tests were performed. Nephrotic range proteinuria, a high creatinine level, bicytopenia along with antinuclear antibody (ANA) and Anti-deoxyribonucleic acid (anti-DNA) positivity were determined in these tests. Systemic lupus erythematosus was considered. Type IV lupus nephritis was also determined with a kidney biopsy. Endoxan $500 \mathrm{mg}$ pulse and methylprednisolone $1000 \mathrm{mg}$ pulse (3 days) were given to the patient parenterally. After these immunosuppressive treatments, the symptoms of the patient relieved, and corticosteroid treatment was continued as methylprednisolone $1 \mathrm{mg} / \mathrm{kg} /$ day at another hospital. The methylprednisolone dosage was not tapered accordingly, and after four months, suffering from fatigue, proximal myopathy, and weakness and

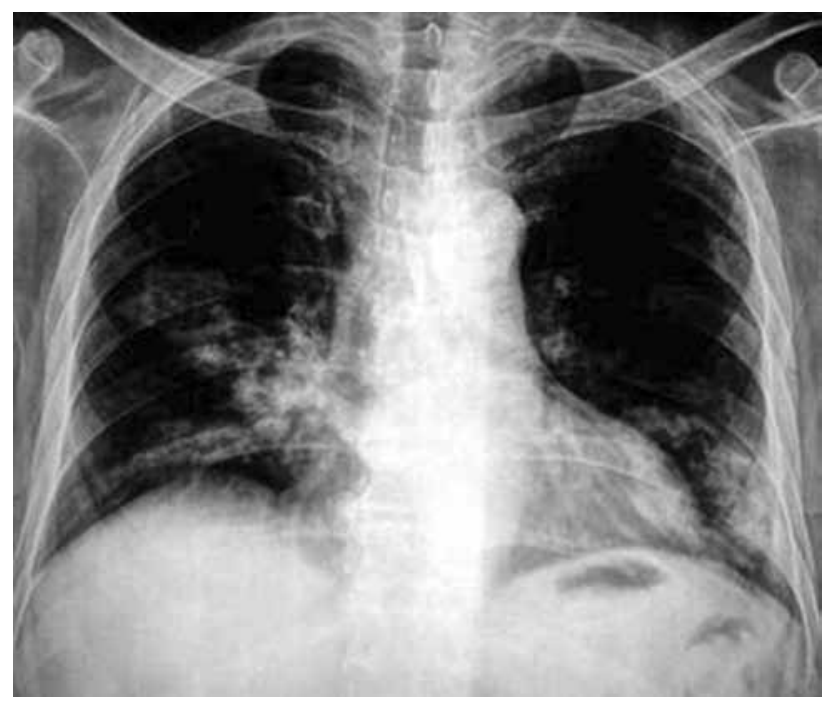

Figure 1. Chest radiograph of the patient. the patient was admitted to our clinic. Upon physical examination, no other finding other than proximal muscle weakness was determined. Laboratory findings were white blood cell count: $12300 / \mathrm{mm}^{3}$, hemoglobin: $8.9 \mathrm{~g} / \mathrm{dl}$, hematocrit: $24 \%$, MCV: $82 \mathrm{fL}$, lymphocyte: $200 \mathrm{~mm}^{3}$, platelet: $63000 \mathrm{~mm}^{3}$. Glucose: $79 \mathrm{~g} / \mathrm{dl}$, BUN: $109 \mathrm{mg} / \mathrm{dl}$, creatinine: $2.7 \mathrm{mg} / \mathrm{dl}$, uric acid: $8.4 \mathrm{mg} / \mathrm{dl}$, $\mathrm{Na}: 135 \mathrm{mmol} / \mathrm{L}, \mathrm{K}: 4.6 \mathrm{mmol} / \mathrm{L}, \mathrm{Cl}: 105 \mathrm{mmol} / \mathrm{L}$, Calcium: $8.2 \mathrm{mg} / \mathrm{dl}, \mathrm{P}: 4.0 \mathrm{mg} / \mathrm{dl}$, AST: $12 \mathrm{U} / \mathrm{L}$, ALT:39 U/L, LDH: 643 U/L, ALP: $70 \mathrm{U} / \mathrm{L}$, and anti-dsDNA of 1:1280. Total bilirubin: $0.48 \mathrm{mg} / \mathrm{dl}$, direct bilirubin: $0.06 \mathrm{mg} / \mathrm{dl}$, Indirect bilirubin: $0.42 \mathrm{mg} / \mathrm{dl}$, total protein: $5 \mathrm{~g} / \mathrm{dl}$, albumin: $2.39 \mathrm{~g} / \mathrm{dl}$, Fe: $73 \mathrm{mcg} / \mathrm{dl}$, Iron binding capacity: $212 \mathrm{mcg} / \mathrm{dl} ., \mathrm{PT}$ : $11.1 \mathrm{sn}, \mathrm{aPTT}: 18.8 \mathrm{sn}$, INR: 0.90 were found. A chest radiograph taken on admission revealed multiple cavitary lesions (Figure 1). A chest computed tomography (CT) also showed multiple cavitary lesions at the sites of the right medial lobe, right inferior lobe superior segment, and left lingula inferior segment along with nodular lesions at the right inferior lobe superior segment (Figure 2). These lesions were found to be related with intensive and long-term steroid treatment. The cavitary lesions were considered as an opportunistic fungal infection, nocardiosis, or tuberculosis. A smear of sputum was negative for both Gram stain and acid fast bacilli, and cultures related to tuberculosis were found to be negative. A bronchoscopy and endobronchial lavage were performed to determine the etiology of these lesions. No endobronchial lesion was observed. Cultures for tuberculosis, nocardiosis, and fungal infections were taken from bronchoalveolar lavage, and also samples were taken for cytologic examination of lavage. In bronchoalveolar lavage

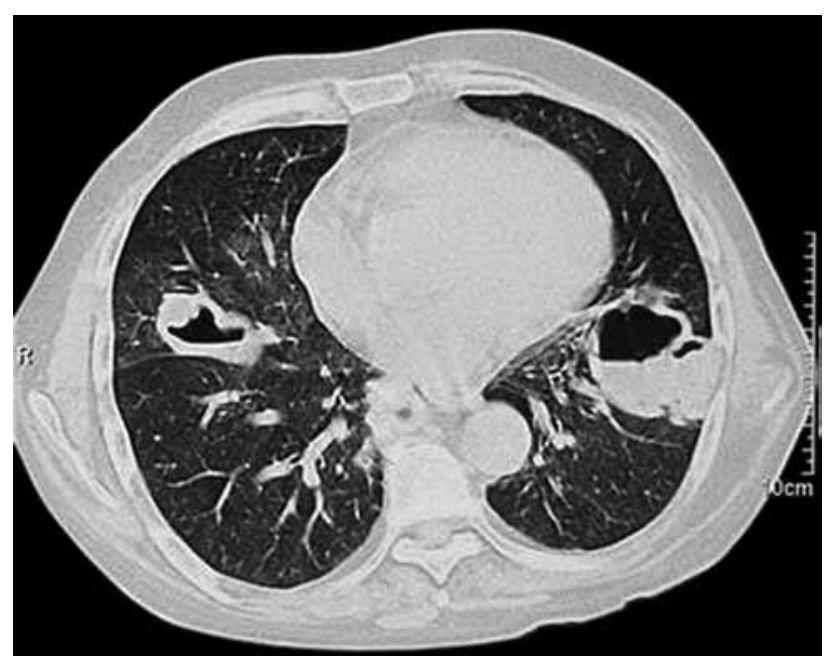

Figure 2. High resolution computed tomography scan of the patient. 
fluid cytology, polymorphonuclear leukocytes was detected, and there were no atypical findings. The sputum specimen was also examined again, and cultures were sterile. The symptoms of the patient had increased progressively. The cavitary lesions had also increased. Because of this progression, high resolution computed tomography (HRCT) was performed. New cavitary lesions were determined at the left pulmonary site in HRCT. Nocardiosis was found positive in bronchoalveolar lavage fluid specimens. The patient was diagnosed as having pulmonary nocardiosis and given intravenous trimethoprim-sulfamethoxazole (320 mg/1600 mg/day), but the patient's clinical findings worsened. Acute respiratory failure developed on the second day of treatment. Metabolic acidosis and respiratory alkalosis were added to the clinical findings. In arterial blood gas, $\mathrm{PH}: 7.31, \mathrm{PCO} 2: 24.8 \mathrm{mmHg}, \mathrm{PO} 2$ : $35.6 \mathrm{mmHg}, \mathrm{HCO}^{3}$ : $12.2 \mathrm{mmol}, \mathrm{O} 2$ saturation: $57.9 \%$ were found. Oxygen inhalation and anti-obstructive treatment were started. Sepsis and acute respiratory distress syndrome were considered possible, and the patient was sent to the intensive care unit. The patient died one day after being sent to the intensive care unit.

\section{DISCUSSION}

Pulmonary nocardiosis is a well-described infection in immunocomprimised patients with malignancy, HIV infection, and in those receiving treatment with corticosteroids and other chemotherapy agents. ${ }^{[1,2]}$ Although originally believed to be fungi, Nocardia are now classified as higher order bacteria and are related to actinomyces. ${ }^{[3]}$ Nocardial infections can be difficult to recognize, which leads to misdiagnosis and, consequently, an underestimation of its incidence. For the same reason, clinical experience remains limited. Pulmonary disease is the predominant clinical presentation (more than $40 \%$ of reported cases) with almost $90 \%$ of these caused by members of the Nocardia asteroides complex..$^{[4]}$ Nocardia species are gaining increased recognition as opportunistic pathogens, although they also cause illness in normal hosts.

Pulmonary nocardiosis produces an impressive variety of roentgenographic findings, such as segmental infiltrates, lobar infiltrates, small and large cavities, necrotizing bronchopneumonia, necrotizing lobar pneumonia, lobar pneumonia with bulging fissures, small and large abscesses, single or multiple nodules, miliary patterns, masses with central cavitations, pleural effusion, and empyema. ${ }^{[5]}$ Because the radiographic feature of nocardiosis is non-specific and pleomorphic with clinical findings ranging from malaise to respiratory failure, it is difficult to diagnose; therefore, the diagnosis of nocardiosis is often delayed. Multiple nodules and cavitation are more commonly described in acquired immune deficiency syndrome (AIDS) patients. ${ }^{[6,7]}$ Multiple cavitary lesions are very rare in non-HIV patients. In our case, the patient was a man with a diagnosis of SLE, and he had undergone corticosteroid treatment for a long time. Although his test was negative for AIDS, multiple cavitary lesions were seen in his chest X-ray and HRCT. Since the patient was HIV-negative and immunosuppressive, all causes of multiple cavitary lung lesions were investigated. Tuberculosis, fungal infections, and malignancy were considered in the differential diagnosis. Multiple cavitary pulmonary nodules can be easily confused with a variety of other bacterial infections of the lung, including actinomycosis and tuberculosis as well as fungal infections and malignancies. In our patient, all of these causes were eliminated after all of the necessary tests were performed.

The microbiology laboratory should always be informed when nocardiosis is suspected because the diagnosis may be missed by routine laboratory methods. Direct smears from specimens typically show gram-positive, beaded, branching filaments which are usually acid fast. Nocardia spp. will grow on most nonselective media used routinely for cultures of bacteria, fungi, and mycobacteria. However, in specimens containing mixed flora (e.g. respiratory secretions), Nocardial colonies are easily obscured by those of more rapidly growing bacteria, and the yield is increased by the use of selective media, such as Thayer-Martin agar with antibiotics or paraffin agar. The growth of Nocardia may take from 48 hours to several weeks, but typical colonies are usually seen within three to five days. Nocardia appear as either buff or pigmented, waxy cerebriform colonies or are chalky white if aerial hyphae are produced. ${ }^{[4]}$ In our patient, nocardiosis diagnosis was confirmed after typical gram-positive, beaded, branching filaments in the bronchoalveolar lavage fluid specimen were shown in the sixth day.

Pulmonary nocardiasis is also a very rare infection in SLE. Its association with lupus has been described only occasionally, and it is difficult to treat. In studies with SLE patients, it is reported that no cases of nocardiosis have been seen in a large group of treated and untreated female SLE patients. Although SLE has a tendency to occur in women, the predisposition of nocardial infection for immunologically suppressed surpassed male subjects appears to hold true in SLE. ${ }^{[8]}$ It was also true for our patient who was male, which 
is similar to most of the published reports. ${ }^{[2,9,10]}$ The reason for this distribution is unclear and may be related to hormonal effects on the virulence or growth of Nocardia. ${ }^{[1]}$ In general, most patients presenting with nocardiosis have a certain degree of immune deficiency. Activated macrophages and $\mathrm{T}$ cells constitute the major defence mechanism for nocardial infection whereas B cells and humoral immunity do not appear to be as important in protecting the host. The most common site of infection is the lungs, where the subacute lung form is the typical manifestation of nocardiosis. ${ }^{[12]}$ However, acute forms are common, especially in severely compromised hosts, ${ }^{[13]}$ and this form seems to be correlated with a poor prognosis. ${ }^{[1]}$

Clinical recognition of nocardial infection is difficult because of its relatively low incidence and a lack of pathognomonic symptoms. Sulfonamide-based regimens have proven to be the most effective treatment for nocardiosis, and trimethoprim-sulfamethoxazole is considered to be the treatment of choice for this disorder.

As shown in our case, pulmonary nocardiosis can be found in unexpected ways, especially in immunosuppressed patients. This patient showed multiple cavitary lesions on chest X-rays. The association of nocardiosis with SLE has only been rarely determined, and its association with acute respiratory distress syndrome has only been reported in one case. ${ }^{[14]}$ In our case, acute respiratory failure was also found because of nocardiosis, and although treatment for infection was started, the patient died within a few days.

In conclusion, nocardiosis may become a severe infection, and it mainly affects profoundly immunocompromised patients. Differential diagnosis, especially with tuberculosis, often delays the time to a proper diagnosis, which worsens the outcome. New diagnostic tools, such as the polymerase chain reaction, could provide more rapid and reliable results. Nocardiosis should always be considered in the differential diagnosis of indolent pulmonary disease, particularly in the setting of cellular immunocompromise. Pulmonary nocardiosis is expected to be a more frequently-encountered disease due to the increasing use of immunosuppressive therapies. The disease should be considered in the differential diagnosis of multiple cavitary pulmonary nodules on chest radiography, even in HIV-negative immunocompromised patients receiving long-term corticosteroid treatment.

\section{Declaration of conflicting interests}

The authors declared no conflicts of interest with respect to the authorship and/or publication of this article.

\section{Funding}

The authors received no financial support for the research and/or authorship of this article.

\section{REFERENCES}

1. Hui $\mathrm{CH}, \mathrm{Au} \mathrm{VW}$, Rowland $\mathrm{K}$, Slavotinek JP, Gordon DL. Pulmonary nocardiosis re-visited: experience of 35 patients at diagnosis. Respir Med 2003;97:709-17.

2. Mari B, Montón C, Mariscal D, Luján M, Sala $M$, Domingo C. Pulmonary nocardiosis: clinical experience in ten cases. Respiration 2001;68:382-8.

3. Reese RE, Douglas RG. A Practical approach to infectious disease 2nd ed. Boston: Little, Brown \& Company; 1986. p. 503.

4. Mandell GL, Bennett JE, Dolin R. Nocardia species. Principles and practice of infectious diseases. 6th ed. Philadelphia: Churchill Livingstone; 2005.

5. Curry WA. Human nocardiosis. A clinical review with selected case reports. Arch Intern Med 1980;140:818-26.

6. Kramer MR, Uttamchandani RB. The radiographic appearance of pulmonary nocardiosis associated with AIDS. Chest 1990;98:382-5.

7. Uttamchandani RB, Daikos GL, Reyes RR, Fischl MA, Dickinson GM, Yamaguchi E, et al. Nocardiosis in 30 patients with advanced human immunodeficiency virus infection: clinical features and outcome. Clin Infect Dis 1994;18:348-53.

8. Gorevic PD, Katler EI, Agus B. Pulmonary nocardiosis. Occurrence in men with systemic lupus erythematosus. Arch Intern Med 1980;140:361-3.

9. Farina C, Boiron P, Ferrari I, Provost F, Goglio A. Report of human nocardiosis in Italy between 1993 and 1997. Eur J Epidemiol 2001;17:1019-22.

10. Pintado V, Gómez-Mampaso E, Fortún J, Meseguer MA, Cobo J, Navas E, et al. Infection with Nocardia species: clinical spectrum of disease and species distribution in Madrid, Spain, 1978-2001. Infection 2002;30:338-40.

11. Kontoyiannis DP, Ruoff K, Hooper DC. Nocardia bacteremia. Report of 4 cases and review of the literature. Medicine (Baltimore) 1998;77:255-67.

12. McNeil MM, Brown JM. The medically important aerobic actinomycetes: epidemiology and microbiology. Clin Microbiol Rev 1994;7:357-417.

13. Torres HA, Reddy BT, Raad II, Tarrand J, Bodey GP, Hanna HA, et al. Nocardiosis in cancer patients. Medicine (Baltimore) 2002;81:388-97.

14. Ferreres Franco J, Blanquer Olivas J, Dosdá Muñoz R, Carbonell Monleón N, Moreno Clari E, Pérez Sancho E. Acute respiratory distress syndrome caused by pulmonary nocardiosis in a patient with systemic lupus erythematosus. Arch Bronconeumol 2005;41:290-2. [Abstract] 